Article

\title{
Sustainable Use and Management of Indigenous Plant Resources: A Case of Mantheding Community in Limpopo Province, South Africa
}

\author{
Sejabaledi A. Rankoana
}

Department of Sociology and Anthropology; University of Limpopo, Private Bag X1106, Sovenga 0727, South Africa; Sejabaledi.rankoana@ul.ac.za; Tel.: +015-268-2179 or +072-443-1321

Academic Editor: Iain Gordon

Received: 24 December 2015; Accepted: 22 February 2016; Published: 3 March 2016

\begin{abstract}
Indigenous plant resources provide rural communities with non-timber forest products that provide energy, food, shelter and medicine. Indigenous plant users in the rural communities have developed selective management methods to sustain plant resources. The most common management methods are restrictions on the cutting of green plants, harvesting of some species during certain seasons, exclusive harvesting of the leaves of certain species and collection of lateral roots from medicinal plant species. The present study examined the use and management strategies developed by members of Mantheding community to sustain indigenous plant resources. The study results are derived from 100 structured interviews and transect walks with key-informants. Multiple uses of indigenous plants are observed. The plants are sources of medicine, food, fodder and fuel. Sustainable management of indigenous plants is accomplished through harvesting practices, seed propagation and control of plant use by the local chief. These management strategies may be referred to as in situ management methods in which the fruits, leaves, roots, bulbs, stem, bark and wood are harvested in their habitats and direct conservation methods are applied to sustain the resources.
\end{abstract}

Keywords: indigenous knowledge; plant resource; sustainability; rural community; Limpopo province

\section{Introduction}

Indigenous plants are sources of non-timber forest products (NTFPs) that provide energy, shelter, food and medicine [1,2]. The Australian Aborigines for instance use a great variety of indigenous plants for a diverse range of purposes such as food, shelter, recreation, medicine and cultural activities [3]. In Southern Africa, rural communities rely on indigenous plants for their livelihoods [4]. In South Asia, the rural poor depend on the NTFPs for their subsistence more than any other part of the world [5]. The forest provides food in the form of fruits, materials for a variety of utensils, and medicinal plants [6]. A higher reliance on indigenous plants in communities of KaLanga chiefdom for the provision of fuel wood, construction timber, food, medicine and carving materials was observed [1].

The use of indigenous plant materials is not a haphazard activity. The local communities have been involved in sustainable use and management of indigenous plant materials since time immemorial [7]. These communities have long devised strategies through which they managed cultural resources using local indigenous knowledge systems [8]. Approaches to conserving plant diversities based on cultural and religious values are often more sustainable than those based only on legislation or regulation [9]. This recognition has greatly contributed towards the development of community-based natural resource management schemes [10]. Several studies proved the effectiveness of traditional ecological knowledge and practices in the protection and maintenance of natural resources [11-16]. It is 
observed that the spiritual beliefs, cosmologies and worldviews are import in the use and management of biodiversity. In Indonesia, local resource management is embedded in the wider socio-cultural context of the local communities [17]. In the Malagasy's spiritual cosmology, the use of taboos for sustainable environmental conservation underlines local people's need for their survival [18]. Taboos may not adequately protect endangered natural resources, but limit destruction of these resources through restrictions on harvesting and collection of the resources [19].

Indigenous plant species are sustained through selective cultural practices $[12,15,20,21]$ where the plant users collect the plant materials through observance of local management practices [22]. Such cultural practices are important in the conservation of biodiversity, rare species, protected areas and ecological processes [9]. Biodiversity management through cultural practices helps strengthen cultural integrity and values $[22,23]$. It is proposed that these knowledge systems should be preserved, expanded and applied [24] to sustain the indigenous plant resources and the livelihood of communities that depend on indigenous plants for food, medicine, fuel and fodder. Article 10(c) of the Convention on Biological Diversity (CBD) proposes the protection and encouragement of customary use of biological resources in accordance with cultural practices compatible with conservation or sustainable use requirements [25].

Cultural practices important for biodiversity management are embedded in taboos, myths, folklore, values and traditional institutions [7]. Traditional beliefs and rituals are the indigenous methods of management of plants adopted to sustain indigenous plants exploited by rural communities $[15,26]$. The most common practices and restrictions among Vhavhenda in South Africa [27] and rural communities in Konta Woreda [28] include barring people from entering some areas of communal lands, cutting green plants, cutting trees in the graveyard, soil collection in the communal lands, harvesting of some species during certain seasons, exclusive harvesting of leaves of certain species, and collection of lateral roots from plants used medicinally.

The goal of the present study was to examine the use and management of indigenous plants in a rural community. As a case study, the study was conducted to document the uses of indigenous plant species and the conservation methods developed by community members to manage the plant resources. The results of the study could be used to develop culture specific sustainable management strategies to preserve indigenous plants of cultural value in the rural communities. Richmond et al. [7] suggests that this type of study could make a contribution towards co-management of plant resources for sustainable and socially just environmental management. Local communities possess a great deal of knowledge about their environments and how to manipulate them to best meet their needs, and therefore, innovative approaches in indigenous plant management are necessary [5]. Such approaches could be based on the understanding of local people's existing knowledge and practices related to forest resource use and management. The complexity of the ecological knowledge of indigenous communities in British Columbia emphasizes that in order to appropriately integrate traditional knowledge into current management systems, its use must be coupled with an understanding of and respect for the culture of the people in which the knowledge is situated [12]. This will, according to Moeng and Potgieter [29], enable communities to manage their environment on ecological principles and benefit economically from becoming stewards over plant biodiversity. Damn [30] reinforces that community conservation activities could lead to the re-establishment of grass-roots democracy and the freedom to control their destinies, which would further improve the socio-economic status of communities. For example the Wapichan people believe that they have a responsibility to care for the land and its resources in order to maintain abundance for present-day communities and for future generations [9]. 


\section{Materials and Methods}

\subsection{Study Area}

Geographically and culturally the Mantheding community belongs to the Dikgale traditional authority settled in the Munnik area about 50 kilometers northeast of Polokwane City, Limpopo Province, South Africa (Figure 1). The community is on the Highveld Plateau, which is bounded in the south and southeast by the Strydpoort Mountain and in the east and northeast by the Wolkberge Mountain. The vegetation is characterized by mixed bushveld. The common vegetation type is the Combretum apiculatum vegetation that consists of small trees, quite dense and sometimes scrub-forest [31].

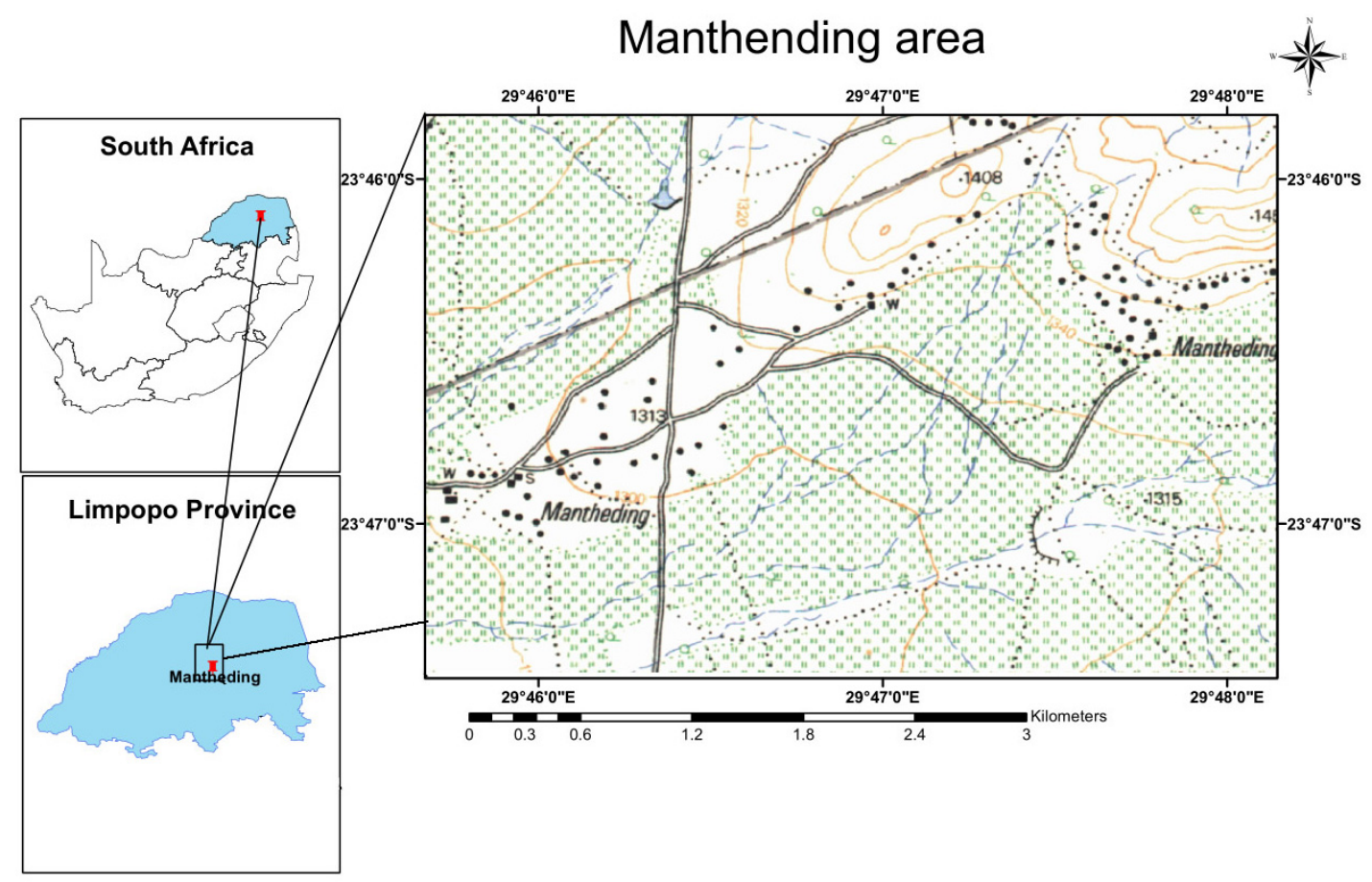

Figure 1. Location of Mantheding community within South Africa and Limpopo Province.

The community lies in a semi-arid climate with an annual rainfall of approximately $505 \mathrm{~mm}$. It has a daily average summer temperature of between $16.9^{\circ} \mathrm{C}$ and $27.8^{\circ} \mathrm{C}$, and a winter average temperature of between $4.3^{\circ} \mathrm{C}$ and $19.8^{\circ} \mathrm{C}$. Summer rainfall occurs between October and April, followed by a dry winter season [32]. The community is under the authority of Chief S. Dikgale. It is dominated by the Northern Sotho tribe with a population of about 963 . The community is a typical rural settlement with diversified and expanded economy and sources of income. Many families still rely on the traditional subsistence economy for their livelihoods, and depend largely on wild plant material for fodder and fuel [33].

\subsection{Participants}

The study participants were selected by means of purposive sampling of men (30), women (30), herdsmen (20), wood-carvers (12) and traditional health practitioners (8). In purposive sampling, the participants are selected on the basis of some specific criteria that are judged to be essential [34]. The researcher deliberately selected community members with a long period of resident in the community, which, according to Rankoana [35], signifies knowledge of the natural environment and the use of natural resources to fulfill basic needs. The participants were all permanent residents of Mantheding community aged between 35 and 82 years. Participation in the study was ensured by signing of a 
consent form. Ethical clearance was obtained from the University of Limpopo Research and Ethics Committee and the data collection instrument was approved by the School of Social Sciences Research and Ethics and the Department of Botany.

\subsection{Data Collection and Analysis}

\subsubsection{Structured Interviews}

The interviews were structured and covered questions pertaining to the uses of indigenous plants and the management methods applied to conserve the plant resources. The research questions were: (1) Which plant species do you know in the wild? (2) What are the plants used for? (3) Which plant parts are harvested for use? The names of the plants known by the participants were recorded in their vernacular names with their uses and the parts harvested for use. The interactions were held in Sepedi, the local dialect of the participants. The voucher specimens of the species were collected, described and pressed during transect walks with participants. The species identified during the study are presented in Table 1. The specimens were identified by taxonomists in the Larry Leach Herbarium of the University of Limpopo. The voucher specimens are deposited in the herbarium for future reference.

Table 1. Indigenous plants used by Mantheding community members.

\begin{tabular}{|c|c|c|c|}
\hline Scientific and Family Names & Local Name & Part Used & Cultural Value \\
\hline $\begin{array}{l}\text { Senegalia burkei. Mimosaceae } \\
\text { SAR } 33\end{array}$ & Mokgwaripa & Dead wood & Fuel \\
\hline $\begin{array}{l}\text { Senegalia erioloba E. Mey. } \\
\text { Mimosaceae SAR } 28\end{array}$ & Mogohlo & Pod, dead wood & Fodder, fuel \\
\hline $\begin{array}{l}\text { Senegalia karroo (Hayne) } \\
\text { Mimosaceae SAR } 2\end{array}$ & Mooka & Dead wood & Fuel \\
\hline $\begin{array}{l}\text { Senegalia mellifera Vahl. Benth } \\
\text { ssp. Mimosaceae SAR } 30\end{array}$ & Mokaka & Dead wood & Fuel \\
\hline $\begin{array}{l}\text { Senegalia tortilis (Forssk) sp. } \\
\text { Mimosaceae SAR } 23\end{array}$ & Mošu & Pod, dead wood & Fodder, fuel \\
\hline $\begin{array}{l}\text { Aloe ferox Mill. Asphodelaceae } \\
\text { SAR43 }\end{array}$ & Sekgophana & Leaf & $\begin{array}{l}\text { Medicine for stomach-ache and } \\
\text { external sores }\end{array}$ \\
\hline $\begin{array}{l}\text { Amaranthus thunbergii Moq. } \\
\text { Amaranthaceae SAR } 16\end{array}$ & Theepe & Leaf & Fodder, vegetable \\
\hline $\begin{array}{l}\text { Aristida congesta Roem \& Schult. } \\
\text { Poaceae SAR } 1\end{array}$ & Motšikiri & Culm & Fodder, broom \\
\hline Aristida sp. Poaceae SAR42 & Kgolane & Culm & Fodder, broom \\
\hline $\begin{array}{l}\text { Artemisia affra Jacq. ex Will. } \\
\text { Asteraceae SAR17 }\end{array}$ & Lengana & Leaf & Medicine for fever, cough \\
\hline $\begin{array}{l}\text { Cleome monophylla } \mathrm{L} \text {. } \\
\text { Capparidaceae SAR22 }\end{array}$ & Lerotho & Leaf & Fodder, vegetable \\
\hline $\begin{array}{l}\text { Curcumis africanus L.f } \\
\text { Curcubitaceae SAR25 }\end{array}$ & Monyaku & Leaf & Fodder, vegetable \\
\hline $\begin{array}{l}\text { Cynodon dactylon (L.) Pers. } \\
\text { Poaceae SAR8 }\end{array}$ & Mohlakahlaka & Culm & Fodder, broom \\
\hline $\begin{array}{l}\text { Dichrostachys cinerea (L.) Wight } \\
\text { \& Arn. Fabaceae SAR12 }\end{array}$ & Moretšhe & Leaf & Fodder, construction \\
\hline $\begin{array}{l}\text { Dicoma gerrardii (Harv. Ex. } \\
\text { ADC) Asteraceae SAR10 }\end{array}$ & Phelalegolana & Bulb & Medicine for cough \\
\hline $\begin{array}{l}\text { Dovyalis caffra (Hook.f. \& Harv.) } \\
\text { Flacourtiaceae SAR5 }\end{array}$ & Mohlono & Fruit, thorn & Protective medicine \\
\hline $\begin{array}{l}\text { Elephantorriza elephantine Burkei } \\
\text { Benth. Fabaceae SAR37 }\end{array}$ & Mošitšana & Leaf & Medicine for diarrhea \\
\hline $\begin{array}{l}\text { Euphorbia tirucalli L. } \\
\text { Euphorbiaceae SAR9 }\end{array}$ & Mohloko & Leaf & $\begin{array}{l}\text { Medicine for snakebites. } \\
\text { Fencing }\end{array}$ \\
\hline $\begin{array}{l}\text { Faidherbia albida (Delile) A. } \\
\text { Chev Fabaceae SAR26 }\end{array}$ & Mokgaba & Twig & Medicine for infertility \\
\hline
\end{tabular}


Table 1. Cont.

\begin{tabular}{|c|c|c|c|}
\hline Scientific and Family Names & Local Name & Part Used & Cultural Value \\
\hline $\begin{array}{l}\text { Gnaphalium helichrysum L. } \\
\text { Asteraceae SAR19 }\end{array}$ & Mohlahlaila & Branch & $\begin{array}{l}\text { Medicine for indigestion, } \\
\text { broom }\end{array}$ \\
\hline $\begin{array}{l}\text { Grewia flavescens. Juss. Tiliaceae } \\
\text { SAR20 }\end{array}$ & Mothetlwa & Leaf & $\begin{array}{l}\text { Fodder, construction of } \\
\text { household utensils }\end{array}$ \\
\hline $\begin{array}{l}\text { Harpagophytum procumbens } \\
\text { (Burch) DC Ex Meisin. } \\
\text { Pedaliaceae SAR31 }\end{array}$ & Lempate & Leaf & $\begin{array}{c}\text { Medicine for indigestion, ease } \\
\text { birth }\end{array}$ \\
\hline $\begin{array}{l}\text { Cf. Hypoxis L. Hypoxidaceae } \\
\text { SAR38 }\end{array}$ & Phela & Bulb & Medicine for cough \\
\hline $\begin{array}{l}\text { Ilex mitis (L.) Radlk. } \\
\text { Aquifoliaceae SAR4 }\end{array}$ & Monamane & Root & Medicine for indigestion \\
\hline $\begin{array}{l}\text { Ipomoea albivenia (Lindlk.) } \\
\text { Sweet. Convolvulaceae SAR7 }\end{array}$ & Leselahlolo & Fruit & Poultice \\
\hline $\begin{array}{l}\text { Kirkia wilmsi Engl } \\
\text { Simaroubaceae SAR27 }\end{array}$ & Modumela & Whole plant & Shade, medicine \\
\hline $\begin{array}{l}\text { Kleinia longiflorus DC. } \\
\text { Euphorbiaceae SAR44 }\end{array}$ & Mmale & Stalks & Medicine for sore eyes \\
\hline $\begin{array}{l}\text { Lippia javanica (Burm F.). } \\
\text { Verbenaceae SAR3 }\end{array}$ & Mošunkwane & Leaf & Medicine for fever, cough, flu \\
\hline Lycium sp. Solanaceae SAR39 & Ngangi & Root & Medicine for stomach-ache \\
\hline $\begin{array}{l}\text { Pappea capensis (Eckl \& Zehl). } \\
\text { Sapindaceae. SAR22 }\end{array}$ & Morobadiepe & Root & Fodder, fuel \\
\hline $\begin{array}{l}\text { Peltophorum Africanum Sond. } \\
\text { Fabaceae SAR15 }\end{array}$ & Mosehla & Bark & $\begin{array}{l}\text { Shade, medicine for } \\
\text { stomach-ache, infertility }\end{array}$ \\
\hline $\begin{array}{l}\text { Raphionacme sp Periplocaceae } \\
\text { SAR35 }\end{array}$ & Tsema & Bulb & $\begin{array}{l}\text { Medicine for acceleration of } \\
\text { growth }\end{array}$ \\
\hline $\begin{array}{l}\text { Ricinus communis L. } \\
\text { Euphorbiaceae SAR11 }\end{array}$ & Mokhure & Leaf & Poultice \\
\hline $\begin{array}{l}\text { Sclerocarya birrea (A. Rich) } \\
\text { Hochst. Anacardiaceae SAR32 }\end{array}$ & Morula & Leaf, dark, fruit, whole plant & $\begin{array}{l}\text { Fodder, medicine for infertility, } \\
\text { fruit, shade, construction of } \\
\text { household utensils }\end{array}$ \\
\hline $\begin{array}{l}\text { Siphonochilus aethiopicus } \\
\text { (Schweif) B.L Burt. } \\
\text { Zingiberaceae SAR34 }\end{array}$ & Serokolo & Bulb & Medicine for tonic, defilement \\
\hline $\begin{array}{l}\text { Solanum panduriforme Bergens. } \\
\text { Solanaceae SAR14 }\end{array}$ & Tholana & Fruit & Medicine for impotency \\
\hline $\begin{array}{l}\text { Sporobolus pyramidalis sp. } \\
\text { Poaceae SAR2 } 4\end{array}$ & Lefielo & Culm & Fodder, broom \\
\hline $\begin{array}{l}\text { Syzygium cordata Hochst ex. } \\
\text { Myrtaceae SAR } 21\end{array}$ & Montlho & Root & $\begin{array}{l}\text { Medicine for tuberculosis, } \\
\text { respiratory disease }\end{array}$ \\
\hline $\begin{array}{l}\text { Trichilia emetica Vahl.subsp. } \\
\text { Meliaceae SAR29 }\end{array}$ & Mmaba & Bark & $\begin{array}{l}\text { Medicine for stomach-ache, } \\
\text { dysentery, indigestion, kidneys }\end{array}$ \\
\hline $\begin{array}{l}\text { Urginea sanguinea Shinz. } \\
\text { Hyacinthaceae SAR13 }\end{array}$ & Sekanama & Bulb & Medicine for blood diseases \\
\hline $\begin{array}{l}\text { Vangueria infausta. } \\
\text { Rubiaceae SAR36 }\end{array}$ & Mmilo & Fruit & Fruit \\
\hline $\begin{array}{l}\text { Warbugia salutaris (G.Bertol). } \\
\text { Canellaceae SAR40 }\end{array}$ & Molaka & Bark & $\begin{array}{c}\text { Medicine for tuberculosis, } \\
\text { intestinal worms, rheumatism, } \\
\text { arthritis }\end{array}$ \\
\hline $\begin{array}{l}\text { Ximenia caffra Sond. Olaceae } \\
\text { SAR18 }\end{array}$ & Motshidi & Root, fruit & Fruit, medicine \\
\hline $\begin{array}{l}\text { Ziziphus mucronata Willd. } \\
\text { Rhamnaceae SAR6 }\end{array}$ & Mokgalo & Leaf & Poultice \\
\hline
\end{tabular}

In determining the management of the plant species, the participants were asked questions about the manner in which they collect the plant materials for different uses. The questions were: (1) Describe the manner of collecting the plant materials for use. (2) What measures are taken to preserve the species? 


\subsubsection{Data Analysis}

Data about the indigenous plant uses and the management methods applied to conserve the plant resources were captured in Microsoft Excel 2007 and analyzed to generate categories of data such as the list of useful plant species, the plant parts used, categories of the uses and the methods of collecting the plant materials for use.

\section{Results}

\subsection{Indigenous Plants of Mantheding Community}

Structured interviews and transect walks documented 44 indigenous plant species belonging to 28 families. The most common species identified belong to Mimosaceae (13.6\%), Poaceae (9\%), Fabaceae (9\%) and Asteraceae (6\%) families. The habits of the species are herbs (9), shrubs (12), trees (15), grass species (4), aloe (1) and creepers (3). All species are harvested in the communal area.

\subsection{The Uses of Indigenous Plants}

According to the participants, knowledge of the use of indigenous plant species identified during the interviews was obtained from their parents, grandparents, relatives and friends. The species are collected throughout the year, with the exception of fruits and vegetables, which are harvested seasonally. Of the species identified, 21 were sources of medicine, five sources of food, six sources of fodder, six sources of fuel and the six sources of material to make household utensils. Instances of commercialization of the species and their products by community members were not mentioned. Household utensils are manufactured for household use only because of the scarcity of the species harvested for this purpose.

\subsection{Preservation of Indigenous Plants}

Structured interviews provided for three methods adopted by the participants to preserve the indigenous plant species to ensure their continued availability and use.

\subsubsection{Collection of Vegetable Sources}

Preservation of the vegetable sources is accomplished through collection of tender leaves, thereby leaving the species to reach maturity, bear seed to regrow in the next season. Forty-two female participants aged 43-61 years reported that the collection of the leaves of Cleome monophylla, Amaranthus thunbergii, and Curcumis africanum is not regulated but only the tender leaves are collected. In the making of tea, the tender leaves of Gnaphalium helichrysum are collected and the whole plant is not cut or pulled out. The availability of Cleome monophylla is magically linked to the way in which the side dishprepared from its leaves, is served. The tender leaves are boiled to make a palatable side dish. It is taboo to spill the side dish into dishes. It should be properly served with a spoon. Failure to observe the prohibition will cause the plant to khuduga (to move or migrate from that place), which means that it will no longer grow in the home garden or its immediate environment. To preserve this important species, many people do not allow non-family members to collect it from their home gardens for fear that they may serve it improperly and endanger its continued availability.

\section{(1) Collection of Fruits}

Preservation of fruit trees according to $78 \%$ women and $22 \%$ males is done by observance of cultural taboos that regulate the collection of fruits. The fruits of Sclerocarya birrea, Vangueria infausta and Ximenia caffra are collected from the ground. There is a taboo on striking the fruit down with a stick, as the plant will be destroyed when it loses some of its leaves and branches. It is believed that if the fruits were struck down, a bad omen in the form of hailstorms would occur and destroy all the 
crops in the fields. The participants asserted that members of the community observe this restriction when they have to collect the fruits.

(2) Harvesting of Grass

Sporobolus pyramidalis, Aristida sp. and Aristida congesta species are preserved by observance of restrictions on their collection. The harvesting of the species is restricted to the culms. The base is not harvested to give the species a chance to regrow in the next season. The species are harvested when they are fully grown in July and August, which is during the time of low economic activity. It is believed that if grass is collected between February and April, when the crops are still in the fields, hailstorm will be invoked and it will destroy the crops in the fields. Preservation of the grass species is further instituted by a fine set up by the chief of the community. The fine varies from R500.00 to R1000.00, depending on the quantity of the grass harvested.

(3) Cutting of Wood for Construction

The harvesting of wood for construction of huts and livestock enclosures is restricted to matured straight stems cut from the opposite sections of Dichrostachys cinerea, Sclerocarya birrea and Pappea capensis to preserve the species. Immature species are not felled for timber harvesting.

\section{(4) Collection of Wood for Fuel}

All participants mentioned that the collection of firewood is confined to the dead wood of Dichrostachys cinerea, Sclerocarya birrea, Pappea capensis and Grewial flavescens. A fine of R1000.00 is imposed on people who cut live wood for fuel. Live species are not collected as firewood. Another measure applicable to preserve the species is a fine of about R1000.00 imposed on community members who collect live species to make firewood.

\section{(5) Harvesting of Medicinal Plants}

Traditional health practitioners asserted that the harvesting of medicinal plants is restricted to thin roots collected from opposite sides of the plant after which soil is replaced. Collection of bark is accomplished by cutting from opposite sides of the trunk. The numbers of leaves collected is limited to a hand-full. These restrictions are observed to sustain the plant species. A taboo on the overexploitation and destruction of medicinal plant species is observed. It is believed that if a medicinal plant species is overexploited, the moya (spirit) that inhabits the plant will cause the medicine prepared out of the species to become ineffective and the disease or condition treated will not be healed because the abode of the spirit (the plant species) is destroyed.

\section{(6) Manufacturing of Household Utensils}

The principle of ensuring continued availability and use of Sclerocarya birrea, Pappea capensis and Dichrostachys cinerea is observed when cutting the wood to make ladles and spoons. Only the straight branches are selected and cut to make these utensils.

\section{(7) Browsing of Fodder}

The plant species browsed by cattle and goats are preserved by avoidance of felling the trees and shrubs as livestock feed. The male participants and stock-herders' responses revealed that cattle, goats and sheep browse the leaves of Senegalia species, Grewia flavescens and Pappea capensis as high as they can reach. The herders do not fell high trees to be browsed by livestock. The pods of Senegalia species and Dichrostachys cinerea are not struck but are browsed from the trees or picked up from the ground after they have been shed. Livestock also browse the shoots of Cleome monophylla, Amaranthus thunbergii and Curcumis africanus (vegetable materials) consumed by human beings. 


\subsubsection{Seed Propagation}

The fruit and vegetable sources are preserved through seed propagation. The participants maintained that the collection and sowing of the seeds of Cleome monophylla lead to the species' wider occurrence. The seeds are collected and scattered in the homesteads and fields. Collection of the fruits of Sclerocarya birrea, Vangueria infausta and Ximenia caffra for family consumption also leads to the dispersal of the seeds and the wider occurrence of the species is ensured.

\subsubsection{Control of the Use of Indigenous Plants by the Chief}

All the participants mentioned that the chief is responsible for management of the local vegetation. The chief has laid down management rules governing the harvesting of indigenous plants. These include restrictions on the cutting of live species for fuel and browse by livestock, and harvesting of immature grass. The chief appointed rangers to monitor the correct harvesting of grass to avoid supernatural intervention in the form of hailstorm and thunders and to ensure continued dependency on indigenous plants. Although the rangers do not have organized and well planned ways of conserving the plant species, they discourage members of the community from the indiscriminate felling of trees for fuel, fodder and collection of fruits. Community members who violate these management rules are liable to a fine in the form of one herd of cattle or R1000.00.

\section{Discussion}

\subsection{The Uses of Indigenous Plants}

The indigenous plant species growing as herbs, shrubs, trees, creepers, grass and aloe are harvested and used by the members of Mantheding community. The plants species fulfill a variety of needs including food, fodder, medicine and fuel. The most common species identified and harvested for use belong to the families of Mimosaceae, Poaceae, Euphorbiaceae, Asteraceae, Fabaceae and Solanaceae. This observation is corroborated by Semenya and Maroyi [36] who attest that in different districts of the Limpopo Province the dominant useful species belong to the families of Fabaceae and Asteraceae. Leakey [37] established that people have always depended on plants for food, shelter, building material and medicine. This dependence continues today throughout the developing world, especially for inhabitants of rural areas $[5,38,39]$. Trees provide resources that cater for the basic human needs in the form of fuel, food, shelter and medicine. In Lesotho, the plant resources provide important social and economic contribution to rural livelihoods [40].

The cultural uses of indigenous plants presented in the study are further supported by observations that the Australian Aborigines use a great variety of wild species for a diverse range of purposes. Many species are harvested as sources of food, shelter, recreation and medicine [3]. De Beer and Van Wyk [41] attest that a wide diversity of plants in the Agter-Hantum in South Africa is still a source of food and medicine. Bobo et al. [42] corroborate these observations that plant species are not only consumed for food, but are also sources of traditional medicine, craft and used for spiritual purposes. In Pakistan the Pir Nasoora National Park provides local communities with native plants on which they depend for their basic livelihood requirements such as fodder, medicines, fodder, fuel, fruits, vegetables, fuel, furniture, and roof thatching [43].

\subsection{Management of Indigenous Plants}

Dependency on indigenous plant species necessitated the development of cultural practices to preserve the species. The harvesting of useful indigenous plant species from communal lands is regulated through observance of strict harvesting methods [44] by all community members who collect the species to satisfy particular needs. Blancas et al. [45] show that people tend to manage plant resources according to their availability and value in households' subsistence. The management methods developed and used in the study include specific harvesting methods, seed propagation and control of the use of plant species by the local chief. 


\subsection{The Harvesting Methods}

Preservation of sources of vegetables is accomplished through harvesting the tender leaves. Species are left to grow to maturity and bear seeds and fruits, which help in the propagation of the species. Collection of fruits is regulated. The taboo restricting the stroking of fruits limits over-use of the fruits trees. The observation by Berkes [9] is that when the Karen look for food, they only collect what they need to eat. The Wapichan have the custom to harvest fruits without felling the tree. Fruit is traditionally harvested by climbing the trees, building a platform or using a gaff to bring down fruit [9]. On the contrary, Shackleton and Shackleton [46] and Sigot [47] show that the widespread disturbance to plant populations in Southern Africa and elsewhere is the harvesting of plants from the wild.

In the study, collection of plant material for construction is limited to straight-stem species. Crooked-stem species are sidelined. Berkes [14] support this finding by showing that when cutting timber trees, the people take care to ensure that they fell the species without damaging the species.

The taboos regulating the harvesting of grass species in the study is aligned to the tenure systems discussed in Turner [6]. For example, the harvesting of grass when it has reached maturity is a fundamental method of sustainable plant resource management. This practice is supported by Warren and Slikkerveer [48] study on the conservation of the natural resources through indigenous knowledge that every culture has restrictions, religiously or socially sanctioned harvesting activities of certain plants by particular people during certain periods throughout the year. Natural features and habitats, often protected by religious taboos and considered sacred by community members, have survived due to strong cultural forces and today act as reservoirs of local biodiversity [49]. Kideghesho [50] and Bobo et al. [42] show that local communities believe in taboos, which, if respected duly, are great conservation measures. Taboos are traditional practices known to have promising potential for enhancing sustainable resource use. Riley [51] examined how the Tonkean macaque is situated in the folklore of villagers in central Sulawesi and revealed that, for many local villagers, the folklore has resulted in a taboo preventing them from harming the macaques, despite the frequent crop-raiding behavior of the species. Sasaoka and Laumonier [17] attest that belief in the power of supernatural agencies influences plant resource management in Amani Oho. In the Malagasy's spiritual cosmology, the use of taboos for sustainable environmental conservation powerfully underlines local people's need to depend on the forest for their survival [18]. Golden and Comaroff [19] show that taboos may not adequately protect endangered species, but limit destruction and overexploitation of useful species.

The study results show that management of medicinal plant resources is done through restrictions and taboos relating to health and illness. The restrictions encourage participants to collect a portion of required plant material to prepare healing decoctions and infusions. Che and Lent [52] observe that herbalists harvesting for medicinal purposes mostly use the leaves or peel a portion of the tree bark facing the sun to allow for rapid regeneration. For Carlson [53] and Nevhutanda [24], protocols and rituals are followed in the harvesting of medicinal species because the life force of living beings is held in the plant species, and that life can be regenerated from the species. Furthermore, restrictions in the harvesting of medicinal plants reduce the species mortality [38] and aid in their conservation [44].

\subsection{Management of Indigenous Plants by Seed Propagation}

Deliberate propagation of the species through dispersal of seeds is another important element applied by the participants for management of indigenous plants. Indigenous fruits and vegetables are propagated through dispersal of seeds in the homesteads for use by family members. This method ensures constant supply of food to the families. This observation is in line with indigenous seed propagation practices in Zimbabwe where tree planting by rural communities is mostly of fruit trees generally confined to the homesteads [54]. 


\subsection{The Role of the Chief in the Management of Indigenous Plants}

The chief in the study community extended his authority duties to monitor compliance to the rules of harvesting of indigenous plant species in his area of jurisdiction. He prevents over-exploitation of the indigenous plant resources by preventing the felling of live species for fuel, and ensuring the harvesting of grass in the correct season. Rasethe et al. [15] concur that chiefs and indunas (headmen of the village) enforce the compliance rules and regulations pertaining to indigenous plant use in the villages. The indigenous plant collectors are monitored through effective leadership to apply sanctions and resolve conflicts over sustainability of the resources [55]. Elsiddig and Jebel [56] and El Gunaid et al. [57] show that the local authorities play a leading role in biodiversity conservation and management, and it is therefore commendable to include them in projects and programs for biodiversity conservation and management. This type of management method ensures community participation in the conservation of useful species to safeguard their continued availability and use [57]. Takadu [58] supports this by showing that communities will strive to conserve useful plant resources by protecting them from being over-used and exploited [59].

\section{Conclusions}

The current study confirms that indigenous plant species still satisfy the needs of rural dwellers in Limpopo Province. The species are harvested for purposes such as maintenance of good health, food, fuel, fodder for livestock, construction and manufacturing of household utensils. Community members have developed mechanisms of reducing indigenous plant species mortality. Indigenous plant use is sustainable in the community. The plants have been the source of livelihood and they are still valued for survival. Continuous use of the plant species is made possible by the methods developed to preserve the species. The species are sustained by the harvesting methods adopted by community members. Such mechanisms are culturally developed management systems known and practiced by community members. Observations of the regulations on the harvesting of plant species uphold common allegiance to the chief of the community. The use and management of plant resources promote environmental conservation and are in situ management methods. The fruits, leaves, roots, bulbs, stems, bark and wood are harvested in their habitats and direct conservation methods are applied to sustain the resources.

Acknowledgments: To the members of Mantheding community in Limpopo Province for their hospitality and receptivity during the fieldwork and for the rich moments of apprenticeship shared.

Conflicts of Interest: The author declares no conflict of interest.

\section{References}

1. Simelane, Z.P. Indigenous Knowledge on Tree Conservation in Swaziland. Master's Thesis, University of the Witwatersrand, Johannesburg, South Africa, 2009.

2. Molewa, E. Minister of Water and Environmental Affairs. A Rich Harvest from Our Natural Resources. Speech Delivered on 13 April 2013. Available online: http://www.iol.co.za/saturday-star/ a-rich-harvest-from-our-resources-1499824 (accessed on 13 June 2015).

3. Strategy for Conservation through Sustainable Use of Wildlife. February 1999. Available online: http:/ / www.lrm.nt.gov.au/_data/assets/pdf_file/0018/11187/sustainable_utilisation_wildlife.pdf (accesses 20 November 2015).

4. Shackleton, C.M., Geach, B.G.S., Eds.; Indigenous Forests and Woodlands in South Africa: Policy, People and Practice; University of KwaZulu-Natal Press: Pietermaritzburg, South Africa, 2004; pp. 253-256.

5. Blockhus, J. Seeing the Wood and the Trees, Special Report: Making the Most of Forests; IUCN: Gland, Switzerland, 1994.

6. Turner, N.J. The Earth's Blanket: Traditional Teachings for Sustainable Living; Douglas \& Mclntyre: Vancouver, BC, USA, 2005. 
7. Richmond, L.; Middleton, B.R.; Gilmer, R. Indigenous studies speak to environmental management. Environ. Manag. 2013, 52, 1041-1045. [CrossRef] [PubMed]

8. Keitumetse, O. Cultural resources as sustainability enablers: Towards a community-based cultural heritage resources management (COBACHREM) mode. Sustainability 2014, 6, 70-85. [CrossRef]

9. Berkes, W.; Colding, J.; Folke, C. Rediscovery of traditional ecological knowledge as adaptive management. Ecol. Appl. 2000, 10, 1251-1262. [CrossRef]

10. Fabricius, C., Koch, E., Turner, S., Magome, H., Eds.; Rights, Resources and Rural Development: Community-Based Natural Resource Management in Southern Africa; Earthscan: London, UK, 2004.

11. Posey, D.A., Ed.; Cultural and Spiritual Values of Biodiversity; UNEP and Intermediate Technology Publications: London, UK, 1999.

12. Turner, N.J.; Ignance, M.B.; Ignance, R.T. Traditional and ecological knowledge and wisdom of Aboriginal Peoples in British Columbia. J. Ecol. Appl. 2000, 10, 1275-1287. [CrossRef]

13. Wiersum, K.F.; Husselman, M.; Dold, A.P.; Cocks, M.L. Cultivation of medicinal plants as a tool for biodiversity conservation and poverty alleviation in the Amatola region, South Africa. In Medicinal and Aromatic Plants, Proceedings of the Frontis Workshop on Medicinal and Aromatic Plants, Wageningen, The Netherlands, 17-20 April 2006.

14. Berkes, F. Religious traditions and biodiversity. Encycl. Biodivers. 2001, 5, 109-120. [CrossRef]

15. Rasethe, M.T.; Semenya, S.; Potgieter, M.J.; Maroyi, A. The utilization and management of plant resources in rural areas of the Limpopo Province, South Africa. J. Ethnobiol. Ethnomed. 2014, 9, 27. [CrossRef] [PubMed]

16. Yadav, U.; Hugo, A.; Yves, B.; Frédérik, D.; Jean-Francois, B. Contribution of traditional knowledge to ecological restoration: practices and applications. Ecoscience 2012, 19, 225-237.

17. Sasaoka, M.; Laumonier, Y. Suitability of Local Resource Management Practices Based on Supernatural Enforcement Mechanisms in the Local Social-cultural Context. Ecol. Soc. 2012, doi:10.5751/ ES-05124-170406. [CrossRef]

18. Golden, C. D. Spiritual roots of the land: hierarchy and relationships of the religious cosmologies of humans and their environment in the Maroantsetra region of Madagascar. Worldviews Glob. Relig. Cult. Ecol. 2014, 18, 255-268. [CrossRef]

19. Golden, C.D.; Comaroff, J. Effects of social change on wildlife consumption taboos in northeastern Madagascar. Ecol. Soc. 2015. [CrossRef]

20. Behera, D.K.; Nath, N.A. Cross-pollination and critique; Resource conservation and utilization through indigenous knowledge in a tribal community of Orissa-India. Indilinga Afr. J. Indig. Knowl. Syst. 2005, 4, 210-227.

21. Muhando, J.A. Cross-pollination critique; Sacred sites and environmental conservation: A case of Kenya. Indilinga Afr. J. Indig. Knowl. Syst. 2005, 4, 228-242.

22. Gardzirayi, C.T.; Mutandwa, E.F.F.; Chihiya, J.; Chikosha, M. Indigenous knowledge systems in sustainable utilization of wetlands in communal areas of Zimbabwe, a case of Hwedza District. J. Agric. Res. 2000, 1, 131-137.

23. Odora-Hoppers, C.A. Indigenous Knowledge and the Integration of Knowledge Systems; New Africa Books: Claremont, Kaapstad, South Africa, 2004.

24. Nevhutanda, M. Arts education in the context of the African Renaissance. In Building on the Indigenous-An African Perspective; Masoga, M., Musyoki, A., Eds.; National Research Foundation: Pretoria, South Africa, 2004.

25. United Nations Development Programme (UNDP). Human Development Report 2011: Sustainability and Equity-A Better Future for All; UNDP: New York, NY, USA, 2011.

26. Ichikawa, B.C.K.; Wong, B.Y.L.; Mulongoy, K.J. Sustainable use of biological diversity in socio-ecological production landscapes, Background to the Satoyama initiative for the benefit of biodiversity and human well-being. Montreal: Secretariat of the Convention on Biological Diversity. Tech. Ser. No. 2010, 52, $22-35$.

27. Khorommbi, K.C. The Role of Venda Culture in Conservation: A Case Study of the Inhabitants of the Tshivhase Area. Master's Thesis, Nelson Mandela Metropolitan University, Port Elizabeth, South Africa, 2002.

28. Bekalo, T.H.; Sebsebe, D.W.; Woldemariam, Z.W. An ethnobotanical study of medicinal plants used by local people in the lowlands of Konta Special Woreda, southern nations, nationalities and peoples regional state. Ethiop. J. Ethnobiol. Ethnomed. 2009. [CrossRef] [PubMed] 
29. Moeng, E.T.; Potgieter, M.J. The trade of medicinal plants by muthi shops and street vendors in the Limpopo Province, South Africa. J. Med. Plants Res. 2011, 5, 558-564.

30. Damn, G.R. The Conservation Game: Saving Africa's Biodiversity. Safari Club International. African Chapter; Interpak Books: KwaZulu-Natal, South Africa, 2002.

31. Acocks, J.P.H. Veld Types of South Africa; Botanical Research Institute: Pretoria, South Africa, 1988.

32. Weather Bureau. Climate of South Africa: Climate Statistics up to 1984; Government Printer: Pretoria, South Africa, 1986.

33. Statistics South Africa. Mid-Year Population Estimates 2011. Statistical Release P0302. Available online: http:/ /www.statssa.gov.za/publications/P0302/P03022011.pdf (accessed on 30 July 2015).

34. Bless, C.; Higson-Smith, C.; Sithole, S.L. Fundamentals of Social Research Methods: An African Perspective; Juta: Cape Town, South Africa, 2013.

35. Rankoana, S.A. The Use of Indigenous Knowledge for Primary Health Care among the Northern Sotho in the Limpopo Province. Ph.D. Thesis, University of Limpopo, Sovenga, South Africa, 2012.

36. Semenya, S.S.; Maroyi, A. Medicinal plants used by the Bapedi traditional healers to treat diarrhoea in the Limpopo Province. S. Afr. J. Ethnopharmacol. 2012, 144, 395-401. [CrossRef] [PubMed]

37. Leakey, R.R.; Al-Qarawi, A.A.; Al-Damegh, M.A.; El-Mougy, S.A. Hepatoprotective Influence of Adansonia digitata pulp. J. Herbs Spices Med. Plants 2003, 10, 1-6.

38. Bélair, C., Ichikawa, K., Wong, B.Y.L., Mulongoy, K.J., Eds.; Sustainable Use of Biological Diversity in Socio-Ecological Production Landscapes: Background to the Satoyama Initiative for the Benefit of Biodiversity and Human Well-beIng; Technical Series No. 52; Secretariat of the Convention on Biological Diversity: Montreal, QC, Canada, 2010.

39. Dovie, D.B.K.; Witkowski, E.T.F.; Shackleton, C.M. The fuel crisis in southern Africa-relating fuelwood use to livelihoods in a rural village. Geogr. J. 2004, 60, 123-133.

40. Letsela, T.; Witkowski, E.T.F.; Balkwill, K. Direct use of communal resources in Bokong and Tsehlanyane in Lesotho: wither the commons? Int. J. Sustain. Dev. World Ecol. 2002, 9, 351-368. [CrossRef]

41. De Beer, J.J.J.; Van Wyk, B.-E. An ethnobotanical survey of the Agte-Hantam, Northern Cape Province, South Africa. S. Afr. J. Bot. 2011, 77, 741-754. [CrossRef]

42. Bobo, K.S.; Aghomo, F.F.M.; Ntumwel, B.C. Wildlife use and the role of taboos in the conservation of wildlife around the Nkwende Hills Forest Reserve; South-west Cameroon. J. Ethnobiol. Ethnomed. 2014. [CrossRef] [PubMed]

43. Amjad, M.S.; Arshad, M.; Qureshi, R. Ethnobotanical inventory and folk uses of indigenous plants from Pir Nasoora National Park, Azad Jammu and Kashmir. Asian Pac. J. Trop. Biomed. 2015, 5, 234-241. [CrossRef]

44. Paumgarten, F.; Shackleton, C.M. Wealth differentiation in household use and trade in non-timber forest products in South Africa. Ecol. Econ. 2009, 68, 2950-2959. [CrossRef]

45. Blancas, J.; Casa, A.; Perez-Salicrup, D.; Caballero, J.; Vega, E. Ecological and socio-cultural factors influencing plant management in Náhuatl communities of the Tejuacán Valley, Mexico. J. Ethnobiol. Ethnomed. 2013. [CrossRef] [PubMed]

46. Shackleton, C.; Shackleton, S. The importance of non-timber forest products in rural livelihood security and as safety nets: A review of evidence from South Africa. S. Afr. J. Sci. 2004, 100, 658-664.

47. Sigot, A.J. Indigenous food systems and promoting sustainable livelihoods. In Building on the Indigenous-An African Perspective; Masoga, M., Musyoki, A., Eds.; National Research Foundation: Pretoria, South Africa, 2004.

48. Warren, D.M., Slikkerveer, L.J., Eds.; The Cultural Dimension of Development: Indigenous Knowledge Systems; SRP: Exeter, UK, 1995.

49. Laird, S.A. Forests, culture and conservation. Cultural and Spiritual Values of Biodiversity, A Complementary Contribution to the Global Biodiversity Assessment; United Nations Environment Programme: Nairobi, Kenya, 1999.

50. Kideghesho, J.R. The potentials of traditional African cultural practices in mitigating overexploitation of wildlife species and habitat loss: experience of Tanzania. Int. J. Biodivers. Sci. Ecosyst. Serv. Manag. 2009, 5, 83-94. [CrossRef]

51. Riley, E.P. The importance of human-macaque folklore for conservation in Lore Lindu National Park, Sulawesi, Indonesia. Oryx 2010, 44, 235-240. [CrossRef] 
52. Che, B.; Lent, P.C. Traditional conservation practices and the use of indigenous forests in the Amatola Mountains of the Eastern Cape Province. In Indigenous Forests and Woodlands in South Africa: Policy, People and Practice; Lawes, M.J., Eeley, H.A.C., Shackleton, C.M., Geach, B.G.S., Eds.; University of KwaZulu-Natal Press: Pietermaritzburg, South Africa, 2004; pp. 253-256.

53. Carlson, R.L. The religious system of the Northwest coast of America. In The Oxford Handbook of the Archaeology of Ritual and Religion; Insoll, T., Ed.; Oxford University Press: Oxford, UK, 2011.

54. Clarke, J. Building on Indigenous Natural Resources Management: Forestry Practices in Zimbabwe's Communal Lands; Forestry Commission: Harare, Zimbabwe, 1994.

55. Sudtongkong, C.; Webb, E.L. Outcomes of state- vs. community-based mangrove management in southern Thailand. Ecol. Soc. 2008, 13, 27.

56. Elsiddig, E.A.; Jebel, M. The Potential for Resources and Rural Development in Darfur; University of Khartoum: Shambat, Sudan, 2007.

57. El Gunaid, F.H.; Elhag, A.M.H.; Dafalla, M.S. The effect of human activities on forest Biodiversity in White Nile State, Sudan. Int. J. Innovat. Appl. Stud. 2013, 2, 547-555.

58. Takadu, O.T. Success factors in community based natural resources management in Northern Botswana: Lessons from practice. Nat. Resour. Forum 2005, 29, 199-212. [CrossRef]

59. Lepofsky, D.; Caldwell, M. Indigenous marine resource management on the Northwest Coast of North America. Ecol. Process 2013. [CrossRef]

(C) 2016 by the author; licensee MDPI, Basel, Switzerland. This article is an open access article distributed under the terms and conditions of the Creative Commons by Attribution (CC-BY) license (http:/ / creativecommons.org/licenses/by/4.0/). 